\title{
Latin American Registry of renal involvement in COVID-19 disease. The relevance of assessing proteinuria throughout the clinical course.
}

Runnig title: Kidney impairment in COVID-19 in Latin America

Raúl Lombardi ${ }^{1}$, Alejandro Ferreiro ${ }^{1}$, Daniela Ponce ${ }^{2}$, Rolando Claure-Del Granado ${ }^{3}$, Gustavo Aroca ${ }^{4}$, Yanissa Venegas ${ }^{5}$, Mariana Pereira ${ }^{6}$, Jonathan Chavez-Iñiguez ${ }^{7}$, Nelson Rojas $^{8}$, Ana Villa ${ }^{9}$, Marcos Colombo ${ }^{10}$, Cristina Carlino ${ }^{11}$, Caio Guimarâes ${ }^{12}$, Mauricio Younes-Ibrahim ${ }^{12-13}$, Lilia Maria Rizo ${ }^{14}$, Gisselle Guzmán ${ }^{15}$, Carlos Varela ${ }^{16}$, Guillermo Rosa-Diez ${ }^{16}$, Diego Janiques ${ }^{12}$, Roger Ayala $^{17}$, Galo Coronel ${ }^{8}$, Eric Roessler ${ }^{18}$, Serena Amor ${ }^{19}$, Washington Osorio $^{20}$, Natalia Rivas ${ }^{21}$, Benedito Pereira ${ }^{22}$, Caroline de Azevedo ${ }^{23}$, Adriana Flores ${ }^{24}$, José Ubillo ${ }^{25}$,Julieta Raño ${ }^{8}$, Luis $\mathrm{Yu}^{26}$, Emmanuel A. Burdmann ${ }^{26}$, Luis Rodríguez ${ }^{27}$, Gianny Galagarza-Gutiérrez ${ }^{28}$, Jesús Curitomay-Cruz ${ }^{29}$.

${ }^{1}$ Department of Nephrology, Universidad de la República, Montevideo, Uruguay.

${ }^{2}$ Clinical Hospital of Botucatu, School Medicine, HCFMB, University of Sao Paulo State UNESP, Brazil.

${ }^{3}$ Hospital Obrero \#2 - C.N.S., School of Medicine, Universidad Mayor de San Simón, Cochabamba, Bolivia.

${ }^{4}$ Universidad Simón Bolívar, Barranquilla, Colombia

${ }^{5}$ Hospital Nacional Arzobispo Loayza, Servicio de Nefrología, Lima, Perú.

${ }^{6}$ School of Medicine, University of São Paulo, Brazil

${ }^{7}$ Division of Nephrology, Hospital Civil de Guadalajara, Mexico.

${ }^{8}$ Departamento de Nefrología, Hospital General de Agudos Dr Cosme Argerich, Buenos Aires, Argentina.

${ }^{9}$ Division of Nephrology, Hospital Civil de Guadalajara, Mexico

${ }^{10}$ Serviço de Nefrología, Santa Casa de Jau, Jau, Brazil.

${ }^{11}$ Department of Nephrology, Hospital Provincial, Rosario, Argentina.

${ }^{12}$ Nefrologia, Pontificia Universidade Catolica do Rio de Janeiro,

Brazil.

${ }^{13}$ Internal Medicine, University of Rio de Janeiro;

${ }^{14}$ Nephrology Hospital Universitario Dr José Eleuterio González, Monterrey, Mexico 
${ }^{15}$ Centros de Diagnóstico y Medicina Avanzada, Santo Domingo, República Dominicana.

${ }^{16}$ Servicio de Nefrología, Hospital Italiano, Buenos Aires, Argentina.

${ }^{17}$ Departamento de Medicina Interna, Salud Renal MSP, Asunción Paraguay.

${ }^{18}$ Department of Nephrology, Pontificia Universidad Catolica de Chile, Santiago, Chile.

${ }^{19}$ Servicio de Nefrología, Hospital Español, Montevideo, Uruguay.

${ }^{20}$ Departamento de Nefrología, Hospital de Especialidades de las Fuerzas Armadas, Quito, Ecuador.

${ }^{21}$ Servicio de Nefrología y Diálisis, Hospital Rojas, Buenos Aires, Argentina

${ }^{22}$ Nephrology, School of Medicine, University of São Paulo, Brazil.

${ }^{23}$ Hospital Federal Cardozo Fontes. Universidade de Sá, Brazil.

${ }^{24}$ Departamento de Nefrología, Hospital Regional General Dr Carlos Mac Gregor Sanchez Navarro, DF, Mexico.

${ }^{25}$ Departamento de Nefrología, Hospital de Pediatría CMN Siglo XXI, DF, Mexico.

${ }^{26}$ Department of Nephrology, School of Medicine, University of Sao Paulo, Sao Paulo, Brazil.

${ }^{27}$ Centro Infantil del Riñón, Tucumán, Argentina

${ }^{28}$ Hospital Regional de Ica, Ica, Perú.

${ }^{29}$ Hospital Nacional Hipólito Unanue, Lima, Perú.

*Corresponding author:

Raúl Lombardi

E-mail: lombardi.raul2@gmail.com 
medRxiv preprint doi: https://doi.org/10.1101/2021.05.01.21256389; this version posted May 4, 2021. The copyright holder for this preprint (which was not certified by peer review) is the author/funder, who has granted medRxiv a license to display the preprint in perpetuity. It is made available under a CC-BY-NC-ND 4.0 International license.

\section{Abstract}

The Latin American Society of Nephrology and Hypertension carried out a cohort prospective, multinational registry of patients with kidney impairment associated to COVID-19 in Latin America through open invitation in order to describe the characteristics of the disease in the region. A population of 870 patients from 12 countries were included. Median age was 63 years (54-74), most of patients were male (68.4\%) and had comorbidities (87.2\%). Acute kidney injury (AKI) was hospital-acquired in $64.7 \%$ and non-oliguric in $59.9 \%$. Multiorgan dysfunction syndrome (MODS) due to COVID-19 and volume depletion were the main causes of AKI $(59.2 \%$ and $35.7 \%$ respectively). Kidney replacement therapy was started in $46.2 \%$. Non-recovery of renal function was observed in $65.3 \% .71 .5 \%$ of patients were admitted to ICU and $72.2 \%$ underwent mechanical ventilation. Proteinuria at admission was present in $62.4 \%$ of patients and proteinuria during hospital-stay occurred in $37.5 \%$. Those patients with proteinuria at admission had higher burden of comorbidities, higher baseline $\mathrm{sCr}$, higher mortality and MODS was severe. On the other hand, patients with de novo proteinuria had lower burden of comorbidities and near normal $\mathrm{sCr}$ at admission, but showed adverse course of disease and higher in-mortality. COVID-19 MODS was the main cause of AKI in both groups. All-cause mortality was $57.4 \%$, and it was associated to age, chronic cardiac disease, fluid depletion, COVID-19 MODS, non-recovery of renal function, ICU admission, vasopressors, in-hospital complications and hospital stay. In conclusion, our study contributes to a better knowledge of this condition and highlights the relevance of the detection of proteinuria throughout the clinical course. Key words: acute kidney injury, proteinuria, COVID-19, mortality, Latin America 
medRxiv preprint doi: https://doi.org/10.1101/2021.05.01.21256389; this version posted May 4, 2021. The copyright holder for this preprint (which was not certified by peer review) is the author/funder, who has granted medRxiv a license to display the preprint in perpetuity. It is made available under a CC-BY-NC-ND 4.0 International license.

\section{Introduction.}

Coronavirus disease 2019 (COVID-19), caused by the coronavirus SARS-CoV-2 is an ongoing pandemic that entails high morbidity and mortality rates. Within a month after the first case was reported on February 2020 in Brazil, all countries in Latin America had reported cases of the novel COVID-19 [1]; and by June 2020 Latin America \& Caribbean became the worlds' latest COVID-19 epicenter with the number of deaths in the region exceeding four million, or over $27 \%$ of the world's covid-19 deaths [2]. Sadly, COVID-19 cases are still growing in the region due to constrained health systems, high prevalence of chronic conditions, delayed responses from governments, and widespread poverty and inequality [3]. Growing evidence has demonstrated that kidney involvement, mainly acute kidney injury (AKI) is prevalent among patients with COVID-19, particularly among critically ill patients affecting approximately $20-40 \%$ of patients admitted to intensive care units $[4,5]$. Similar to the association of AKI with other forms of community-acquired pneumonia [6], AKI is now recognized as a common complication of COVID-19 and as with AKI from other causes, is associated with adverse outcomes [7]. On the other hand, disturbances of the urinary sediment has not been extensively studied in spite its known value. Available information on epidemiology and risk factors for AKI in the region is generally scarce, and this situation has not improved during the COVID-19 pandemic [8]. Knowledge of patient characteristics, risk factors and adverse outcomes, as well as regional peculiarities is key in the fight against this new disease. Taking into account the high incidence of AKI, its high mortality rate and the limited attention given to the associated alterations of the urinary sediment in the region, the AKI Committee of the Latin American Society of 
medRxiv preprint doi: https://doi.org/10.1101/2021.05.01.21256389; this version posted May 4, 2021. The copyright holder for this preprint (which was not certified by peer review) is the author/funder, who has granted medRxiv a license to display the preprint in perpetuity. It is made available under a CC-BY-NC-ND 4.0 International license.

Nephrology and Hypertension (SLANH) carried out a prospective cohort study in order to improve the knowledge of this devastating pandemic in Latin America.

\section{Methods and patients}

This is an observational, prospective, longitudinal, multinational cohort study based on a registry carried out between May $1^{\text {st }} 2020$ and December 31th 2020. An open invitation to participate in the Registry was made through the webpage of the SLANH, the National Societies of Nephrology and by personal email sent to members of RedIRA (Latin American AKI-Network) a networked learning tool of SLANH (http://redira.slanh.net/). Participation in the Registry was voluntary, without any incentive or economic benefit for patients or investigators. Data were obtained from the clinical record of patients and were entered online by the participants in a Surveymonkey ${ }^{\circledR}$ platform specifically designed for this purpose (https://es.surveymonkey.com/r/L6PVMGQ). The form has six sections that include: 1) country and city of residence, plus demographic data; 2) comorbidities and condition at admission; 3) laboratory at admission; 4) characteristics and causes of AKI; 5) ICU admission, mechanical ventilation (MV) and in-hospital complications; 6) condition at discharge (S1 Table 1. Form for data colection). Potential bias could exists considering that is a registry of non-consecutive patients. Periodical reminders were sent to participants in order to reduce the rate of non-response and loss of follow-up. We also sent follow-up reminders of incomplete cases throughout the registry with the intention of completing missing cases. Inclusion criteria included adult and children with COVID-19 infection confirmed by RT-PCR of nasopharyngeal swabs and acute kidney injury (AKI) defined by KDIGO 2012 sCr criteria, and/or urinary sediment 
medRxiv preprint doi: https://doi.org/10.1101/2021.05.01.21256389; this version posted May 4, 2021. The copyright holder for this preprint (which was not certified by peer review) is the author/funder, who has granted medRxiv a license to display the preprint in perpetuity.

It is made available under a CC-BY-NC-ND 4.0 International license.

abnormalities (proteinuria/hematuria). Exclusion criteria: included patients with

chronic kidney disease (CKD) stage 5, patients on chronic dialysis or transplanted.

\section{Definitions}

Acute kidney injury was identified according to KDIGO definition when occurred an increase in serum creatinine level $\geq 0.3 \mathrm{mg} / \mathrm{dl}$ within 48 hours or by $50 \%$ within 7 days. For the detection of proteinuria or hematuria, the semiquantitative dipstick test was used. Renal recovery was considered when $\mathrm{sCr}$ returned to baseline or reference value or lower. Non-recovery was established when $\mathrm{s} C r$ did not decrease or if the patient remained on dialysis. AKI was considered as community-acquired (CA-AKI) when patient had an elevated SCr within the first 24 hours of admission and hospitalacquired (HA-AKI) when AKI developed during hospital stay.

Condition on admission to the hospital was classified in three categories: mild, if the patient was admitted to a conventional ward without need for oxygen therapy; moderate, if the patient required oxygen therapy; and severe, if the patient was admitted to the intensive care unit (ICU).

Bioethical considerations: the Institutional Review Board of the Clínica Los Olivos, Cochabamba, Bolivia (contact Dr. Esdenka Vega, administracion@clinicalosolivos.com) approved the study. The informed consent was considered not mandatory by the reference IRB given the observational characteristic of the study. Protocol and forms are available on the study's website (https://slanh.net/registro-latinoamericano-iracovid-19/). Confidentiality of information was appropriately protected by deidentification of data. No personal data of patients was included in the form. 
medRxiv preprint doi: https://doi.org/10.1101/2021.05.01.21256389; this version posted May 4, 2021. The copyright holder for this preprint (which was not certified by peer review) is the author/funder, who has granted medRxiv a license to display the preprint in perpetuity.

It is made available under a CC-BY-NC-ND 4.0 International license.

Together with the registry, a short survey aimed to know working conditions, difficulties and challenges faced in the course of the pandemic was carried out during the study (S1 Table 2. Results of an open survey of Latin-American nephrologist participants and no participants of the Registry coming from 14 countries. Answers are expressed in percentage).

SLANH provided financial support for the design and maintenance of the platform during the recruitment period, as well as for the publishing fees. The funder had no role in study design, data collection and analysis, decision to publish, or preparation of the manuscript. Competing interests: The authors have declared that no competing interests exist.

\section{Statistical analysis}

Quantitative variables are presented as median and interquartile range (IQR) according to their distribution, and the categorical variables as number and proportions.

Kolmogorov-Smirnov test was used to explore the data distribution. For the bivariate comparisons between groups, the Chi square test was used for categorical variables and the $U$ Mann-Whitney test or the Kruskal-Wallis test for quantitative variables. Odds ratio and 95\% Confidence Interval $(\mathrm{Cl})$ were also calculated. Statistical tests were two-sided and significance was considered with a probability of null hypothesis $\leq 5 \%$. A multiple logistic regression model was performed to predict mortality using the forward conditional elimination method. The probability for entering the model was set at 0.10 and for elimination at 0.20 . Variables that reached a significance 
medRxiv preprint doi: https://doi.org/10.1101/2021.05.01.21256389; this version posted May 4, 2021. The copyright holder for this preprint (which was not certified by peer review) is the author/funder, who has granted medRxiv a license to display the preprint in perpetuity. It is made available under a CC-BY-NC-ND 4.0 International license.

$<0.10$ in the univariate analysis were included. The statistical package IBM SPSS

Statistics Base version 22 NY, USA, was used for data processing and for statistical analysis.

\section{Results}

The overall results of the entire population are presented all together and some subgroups considered of particular interest are described separately.

\section{Descriptive analysis of the entire population}

Forty participants from 52 cities in 12 countries entered 967 patients in the Registry. Ninety-seven patients were excluded due to lack of data on outcomes, remaining 870 patients for the analysis. Median age was 63 (54-74) years; 595 were male (68.4\%).

Distribution of patients by country is shown in Fig. 1. Patients per country. Of the 870 patients 759 (87.2\%) had one or more comorbidities being hypertension, diabetes and obesity prevalent among others (Table 1).

Table 1. Comorbid conditions

\begin{tabular}{|l|c|}
\hline Comorbidities & N (\%) \\
\hline Hypertension & $536(61.1)$ \\
\hline Diabetes & $341(39.4)$ \\
\hline Obesity & $278(32.0)$ \\
\hline Cardiovascular disease & $135(15.5)$ \\
\hline Chronic Kidney Disease & $117(13.4)$ \\
\hline Chronic Obstructive Pulmonary Disease & $60(6.9)$ \\
\hline Immunodepression & $23(2.7)$ \\
\hline None & $111(12.8)$ \\
\hline Other & $166(19.1)$ \\
\hline
\end{tabular}

Time between diagnosis of COVID-19 and hospital admission was $2(0-4)$ days and condition at hospital admission was mild in 121 (14.0\%); moderate in 384 (44.2\%) and 
medRxiv preprint doi: https://doi.org/10.1101/2021.05.01.21256389; this version posted May 4, 2021. The copyright holder for this preprint (which was not certified by peer review) is the author/funder, who has granted medRxiv a license to display the preprint in perpetuity. It is made available under a CC-BY-NC-ND 4.0 International license.

severe in 363 (41.8\%). Table 2 shows laboratory findings at admission and during hospital stay.

Table 2 Laboratory data at admission and during hospital stay

\section{Variable}

Scr at admission $\mathrm{mg} / \mathrm{dL}$

Serum potassium at admission $\mathrm{mmol} / \mathrm{L}$

WBC at admission mm3

Platelets $\times 1000$ at admission

INR at admission

Ferritine at admission (ng/ml)

$\mathrm{pH}$ at admission

$\mathrm{HCO} 3$ at admission $\mathrm{mmol} / \mathrm{L}$

AST at admission (U/L)

ALT at admission (U/L)

CK at admission (U/L)

Scr peak $(\mathrm{mg} / \mathrm{dL})$

Minimum $\mathrm{PaO}_{2} / \mathrm{FiO}_{2}$

Minimum PEEP $\left(\mathrm{cmH}_{2} \mathrm{O}\right)$

Last available Scr (survivors) (mg/dL)

Last available Scr (deceased) (mg/dL)

\section{Median (IQR)}

$1.20(0.90-1.93)$

$4.2(3.9-4.8)$

$10400(7800-14137)$

$236(174-302)$

$1.1(1.00-1.26)$

1067 (554-1895)

$7.39(7.30-7.43)$

$22(19-24)$

$38(23-63)$

$32(20-55)$

$168(81-421)$

$3.60(1.97-5.20)$

134 (112-180)

$14(12-15)$

1.08 (0.81-1.95)

$3.40(2.11-4.90)$ 
medRxiv preprint doi: https://doi.org/10.1101/2021.05.01.21256389; this version posted May 4, 2021. The copyright holder for this preprint (which was not certified by peer review) is the author/funder, who has granted medRxiv a license to display the preprint in perpetuity. It is made available under a CC-BY-NC-ND 4.0 International license.

Of note, about half of patients had a serum creatinine at admission within normal values. In 388 patients a urine dipstick test was performed showing some degree of proteinuria in $242(62.4 \%):+151 ;++64 ;+++22 ;++++5$. Hematuria was present in 144 out of 390 cases (36.9\%). Thirty-nine out of 104 patients (37.5\%) developed proteinuria during their hospital stay. AKI was hospital-acquired in 547 (62.9\%). Time between diagnosis of COVID-19 and the onset of AKI was 3 (1-7) days. Recorded causes of AKI according to providers' at each participant center are listed in Table 3 being multi-organ dysfunction (MODS) attributable to SARS-CoV-2 infection the most prevalent.

Table 3. Presumed etiology of acute kidney injury, single or in combination

\begin{tabular}{|l|c|}
\hline Etiology & N (\%) \\
\hline SARS-CoV-2 MODS* & $515(59.2)$ \\
\hline Hypovolemia/dehydration & $311(35.7)$ \\
\hline Sepsis MODS & $254(29.2)$ \\
\hline Nephrotoxic drugs & $182(20.9)$ \\
\hline Rhabdomyolisis & $10(1.2)$ \\
\hline Other causes & 110 \\
\hline
\end{tabular}

*MODS: multiorgan dysfunction syndrome

As expected, in most patients the etiology of AKI was multifactorial or was atributed to more than one exposure. In many patients AKI was linked to more than one etiology. In the majority of cases AKI was non-oliguric (59.9\%) and hospital acquired (64.7\%). Most patients had KDIGO stage 3 AKI (59.7\%) followed by stage 1 (25.8\%) and stage 2 (14.5\%). Kidney replacement therapy (KRT) was performed in 402 patients (46.2\%) and was associated to the level of $\mathrm{sCr}$ at admission (OR 1.32, 95\% Cl 1.00-1.74, $\mathrm{p}=0.049$ ); admission pH (OR 0.01, 95\% Cl 0.00-0.44, p=0.016); hospital-acquired AKI (OR 4.26, 95\% Cl 1.90-9.56, p=0.000); COVID-19 MODS (OR 5.52 95\%Cl 2.82-10.82, $p=0.000$ ); and 
medRxiv preprint doi: https://doi.org/10.1101/2021.05.01.21256389; this version posted May 4, 2021. The copyright holder for this preprint (which was not certified by peer review) is the author/funder, who has granted medRxiv a license to display the preprint in perpetuity. It is made available under a CC-BY-NC-ND 4.0 International license .

oliguria (OR 5.97, 95\% Cl 2.89-12.34, p=0.000). Forty-three patients with indication for KRT didn't receive it (4.9\%) having a higher mortality than the general population (86\% vs $62.5 \%)$. The reason for not starting KRT was not recorded in each of those cases, but presumably was due to shortage of resources, as can be supported by a contemporary survey answered by 140 Latin American nephrologists $18.3 \%$ of them refer having assisted patients who needed KRT but could not receive it (S1 Table 2). The most common type of KRT was intermittent hemodialysis (IHD) (32.4\%), followed by prolonged intermittent kidney replacement therapy (PIKRT) (15.2\%), continuous kidney replacement therapy (CKRT) (7.2\%) and peritoneal dialysis (PD) (1.2\%). In the remaining $0.4 \%$ cases other procedures such as hemofiltration and hemoadsorption was performed. Patients were treated for SARS-CoV-2 infection with steroids in $73.9 \%$; oseltamivir in $18.7 \%$; chloroquine-hydroxychloroquine in $12.5 \%$; ivermectine in $6.8 \%$; tocilizumab in $1.5 \%$; remdesivir and linipovir-ritonavir in $0.6 \%$. It should be highlighted that in a large proportion of patients the option "other treatment" was selected in 46.9\% with no further clarification. Most of the patients had complications during the hospitalization prevailing sepsis in $50.4 \%$ of cases followed by infection without sepsis (8.7\%) and deep venous thrombosis (5.4\%). Clinical course was severe as expressed by the high number of critically ill patients needing mechanical ventilation $(71.5 \%$ and $72.2 \%$ respectively). As what it was observed with KRT some patients who required ICU and/or mechanical ventilation were not admitted or placed on mechanical ventilation due probably to limited availability of resources in some centers. It should be noted that 6 patients were placed on mechanical ventilation outside the ICU. Renal recovery was observed in $35.2 \%$ of patients. All-cause in-hospital mortality was $62.5 \%$ (544 out of 870 patients). Of the 544 deceased patients 479 (88.0\%) died in ICU. Among 
medRxiv preprint doi: https://doi.org/10.1101/2021.05.01.21256389; this version posted May 4, 2021. The copyright holder for this preprint (which was not certified by peer review) is the author/funder, who has granted medRxiv a license to display the preprint in perpetuity. It is made available under a CC-BY-NC-ND 4.0 International license .

survivors, 135 (41.4\%) were in ICU and discharged alive from the hospital. Table 4 shows the variables associated to mortality in the univariate analysis and Table 5 the results of the logistic regression model. Variables with more than $30 \%$ missing data or inconsistency were excluded from the model (ferritine, platelets count, INR, CK, $\left.\mathrm{PaO}_{2} / \mathrm{FiO}_{2}\right)$.

Table 4 Risk factors for in-hospital mortality. Univariable analysis. 
medRxiv preprint doi: https://doi.org/10.1101/2021.05.01.21256389; this version posted May 4, 2021. The copyright holder for this preprint (which was not certified by peer review) is the author/funder, who has granted medRxiv a license to display the preprint in perpetuity. It is made available under a CC-BY-NC-ND 4.0 International license .

\begin{tabular}{|c|c|c|c|}
\hline Variable & $\begin{array}{c}\text { Death } \\
544\end{array}$ & $\begin{array}{c}\text { Alive } \\
326\end{array}$ & $\mathbf{P}$ \\
\hline Age yrs & $65(57-75)$ & $59(48-69)$ & 0.000 \\
\hline $\begin{array}{l}\text { Comorbidities } \mathrm{n}(\%) \\
\text { Cardiovascular disease } \\
\text { Obesity }\end{array}$ & $\begin{array}{c}94(17.3) \\
199(36.6)\end{array}$ & $\begin{array}{l}41(12.6) \\
79(24.2)\end{array}$ & $\begin{array}{l}0.038 \\
0.000\end{array}$ \\
\hline $\begin{array}{l}\text { Condition at admission } \mathrm{n}(\%) \\
\text { Mild } \\
\text { Moderate } \\
\text { Severe }\end{array}$ & $\begin{array}{c}36(6.6) \\
237(43.6) \\
270(49.7)\end{array}$ & $\begin{array}{c}85(26.2) \\
147(45.2) \\
93(28.6)\end{array}$ & 0.000 \\
\hline Scr mg/dL & $1.20(0.90-1.80)$ & $1.32(0.97-2.31)$ & 0.000 \\
\hline Proteinuria at admission (n 245) & $171(69.8)$ & $74(30.2)$ & 0.000 \\
\hline White blood cell count $\mathrm{mm} 3$ & $11200(8225-15795$ & $9559(6975-12710)$ & 0.000 \\
\hline Ferritine $\mathrm{ng} / \mathrm{ml}$ & $1285(689-2000)$ & $840(366-1307)$ & 0.000 \\
\hline CK U/L & $228(99-669)$ & $123(60-250)$ & 0.000 \\
\hline Hospital-acquired AKI n (\%) & $399(74.0)$ & $148(48.2)$ & 0.000 \\
\hline $\begin{array}{l}\text { Cause of AKI n (\%) } \\
\text { Hiyovolemia } \\
\text { MODS* SARS-CoV2 } \\
\text { MODS sepsis } \\
\text { Nephrotoxic drugs }\end{array}$ & $\begin{array}{l}156(28.7) \\
376(69.1) \\
207(38.1) \\
99(18.2)\end{array}$ & $\begin{array}{l}155(47.59 \\
139(42.6) \\
47(14.4) \\
83(25.5)\end{array}$ & $\begin{array}{l}0.000 \\
0.000 \\
0.000 \\
0.007\end{array}$ \\
\hline Oliguric AKI & $259(48.3)$ & $77(25.0)$ & 0.000 \\
\hline Scr peak $\mathrm{mg} / \mathrm{dL}$ & $4.10(2.80-5.47)$ & $2.15(1.49-4.40)$ & 0.000 \\
\hline Kidney replacement therapy & $315(58.0)$ & $87(27.0)$ & 0.000 \\
\hline Non-recovery of renal function & $462(88.5)$ & $71(23.7)$ & 0.000 \\
\hline Duration of kidney replacement therapy (days) & $6(3-11)$ & $10(5-27)$ & 0.000 \\
\hline Admission to ICU & $484(89.3)$ & $138(42.3)$ & 0.000 \\
\hline Mechanical ventilation & $492(90.6)$ & $136(42.1)$ & 0.000 \\
\hline Minimum $\mathrm{PaO}_{2} / \mathrm{FiO}_{2}$ & $123(108-157)$ & $164(123-237)$ & 0.000 \\
\hline New onset of proteinuria & $106(32.8)$ & $57(24.1)$ & 0.015 \\
\hline New onset of hematuria & $101(30.9)$ & $32(13.7)$ & 0.000 \\
\hline Last available Scr mg/dL & $3.40(2.10-4.90)$ & $1.07(0.82-1.90)$ & 0.000 \\
\hline $\begin{array}{l}\text { Complications (\%) } \\
\text { Sepsis } \\
\text { Infection } \\
\text { No complications }\end{array}$ & $\begin{array}{l}360(67.2) \\
22(4.3) \\
51(9.9)\end{array}$ & $\begin{array}{c}79(25.1) \\
54(17.4) \\
110(34.9)\end{array}$ & $\begin{array}{l}0.000 \\
0.000 \\
0.000\end{array}$ \\
\hline Hospital stay (days) & $13(8-21)$ & $14(8-28)$ & 0.046 \\
\hline
\end{tabular}

*MODS: multiorgan dysfunction syndrome 
medRxiv preprint doi: https://doi.org/10.1101/2021.05.01.21256389; this version posted May 4, 2021. The copyright holder for this preprint (which was not certified by peer review) is the author/funder, who has granted medRxiv a license to display the preprint in perpetuity. It is made available under a CC-BY-NC-ND 4.0 International license.

Table 4. Risk factors independently associated to in-hospital mortality. Multivariable logistic regression analysis.

\begin{tabular}{|l|c|c|}
\hline & OR (Cl 95\%) & $p$ \\
\hline Age (yrs) & $0.963(0.949-0.986)$ & 0.002 \\
\hline Chronic cardiac disease & $2.867(1.142-7.195)$ & 0.025 \\
\hline Cause of AKI & & \\
Fluid depletion & $2.180(1.076-4.420)$ & 0.031 \\
MODS* due to Covid-19 & $2.211(1.051-4.652)$ & 0.037 \\
\hline Non recovery of renal function & $31.719(15.46-65.076)$ & 0.000 \\
\hline ICU admission & $38.536(11.864-125.168$ & 0.000 \\
\hline Vasopressor use & $3.952(1.513-10-321)$ & 0.005 \\
\hline In-hospital complication & $3.30(1.42-7.79)$ & 0.006 \\
\hline Length of hospital stay (days) & $1.046(1.025-1.067)$ & 0.000 \\
\hline
\end{tabular}

*MODS: multiorgan dysfunction syndrome

\section{Subgroup I. Patients with proteinuria on admission}

Characteristics of subgroup I are shown in Table 6.

Table 6. Clinical characteristics of patients with proteinuria at admission. Subgroup I.

\begin{tabular}{|l|c|c|c|}
\hline Variable & $\begin{array}{c}\text { Proteinuria } \\
\text { No proteinuria }\end{array}$ & $p$ \\
\hline $\begin{array}{l}\text { Comorbidities } \mathrm{n}(\%) \\
\text { Hypertension } \\
\text { Chronic kidney disease }\end{array}$ & $165(67.3)$ & $85(57.4)$ & 0.039 \\
\hline No comorbidities & $54(22.0)$ & $7(4.7)$ & 0.000 \\
\hline $\begin{array}{l}\text { Cause of acute kidney injury } \\
\text { SARS-CoV-2 MODS }\end{array}$ & $23(9.4)$ & $2416.2)$ & 0.032 \\
\hline Scr at admission mg/dl & $162(66.1)$ & $83(56.1)$ & 0.030 \\
\hline Serum potassium at admission & $1.39(0.90-2.64)$ & $0.99(0.80-1.30)$ & 0.000 \\
\hline Scr peak mg/dL & $4.35(4.00-5.02)$ & $4.10(3.80-4.40)$ & 0.000 \\
\hline
\end{tabular}


medRxiv preprint doi: https://doi.org/10.1101/2021.05.01.21256389; this version posted May 4, 2021. The copyright holder for this preprint (which was not certified by peer review) is the author/funder, who has granted medRxiv a license to display the preprint in perpetuity. It is made available under a CC-BY-NC-ND 4.0 International license.

\begin{tabular}{|l|c|c|c|}
\hline Kidney replacement therapy & $136(56.0)$ & $60(40.8)$ & 0.006 \\
\hline Renal function recovery & $59(25.5)$ & $61(47.7)$ & 0.000 \\
\hline ICU admission & $195(79.9)$ & $100(67.6)$ & 0.02 \\
\hline Mechanical ventilation & $198(81.1)$ & $101(68.2)$ & 0.013 \\
\hline Vasopressors & $158(67.2)$ & $74(53.2)$ & 0.005 \\
\hline In-hospital complication & $23(9.4)$ & $33(22.7)$ & 0.001 \\
\hline Infection & & & 0.000 \\
\hline Last available Scr mg/dL & $3.00(1.60-4.50)$ & $1.56(0.90-3.14)$ & 0.000 \\
\hline Mortality & $171(69.8)$ & $74(50.0)$ & \\
\hline
\end{tabular}

In summary, this subgroup of patients had higher burden of comorbidities, and elevated $\mathrm{SCr}$ and potassium at admission. AKI was linked to COVID-19 MODS and showed worse outcomes (severity of the disease and mortality). Within the Subgroup I, 34 out of 393 patients did not developed AKI. As expected those cases had milder forms of COVID-19 at admission and had a less severe clinical course during hospitalization (need of ICU, MV, vasopressors, and mortality).

\section{Subgroup II. Patients with normal urinary sediment on admission and de novo}

\section{proteinuria during hospital stay.}

Of 104 patients in whom urinary sediment was assessed during their hospitalization, 39 (37.5\%) of them developed de novo proteinuria. Clinical characteristics are shown in Table 7.

Table 7. Characteristics of patients who developed de novo proteinuria. Subgroup II. 
medRxiv preprint doi: https://doi.org/10.1101/2021.05.01.21256389; this version posted May 4, 2021. The copyright holder for this preprint (which was not certified by peer review) is the author/funder, who has granted medRxiv a license to display the preprint in perpetuity. It is made available under a CC-BY-NC-ND 4.0 International license.

\begin{tabular}{|c|c|c|c|}
\hline Variable & $\begin{array}{c}\text { Proteinuria } \\
39\end{array}$ & $\begin{array}{l}\text { No proteinuria } \\
65\end{array}$ & $\mathbf{P}$ \\
\hline Male n (\%) & $33(84.6)$ & $43(66.2)$ & 0.032 \\
\hline $\begin{array}{l}\text { Comorbidities } \\
\text { Hypertension } \\
\text { No comorbidities }\end{array}$ & $\begin{array}{c}27(69.2) \\
3(7.7)\end{array}$ & $\begin{array}{l}30(46.2) \\
16(24.6)\end{array}$ & $\begin{array}{l}0.018 \\
0.025\end{array}$ \\
\hline $\begin{array}{l}\text { Cause of acute kidney injury } \\
\text { Dehydration/volume depletion } \\
\text { SARS-CoV-2 MODS } \\
\text { Nephrotoxic drugs }\end{array}$ & $\begin{array}{l}5(12.8) \\
37(94.9) \\
2(5.1)\end{array}$ & $\begin{array}{l}30(46.2) \\
26(40.0) \\
14(21.5)\end{array}$ & $\begin{array}{l}0.000 \\
0.000 \\
0.020\end{array}$ \\
\hline Scr at admission & $0.90(0.90-1.00)$ & $1.00(0.80-1.40)$ & 0.016 \\
\hline Scr peak mg/dL & $4.80(3.40-6.20)$ & $1.80(1.05-3.70)$ & 0.000 \\
\hline Kidney replacement therapy & $33(84.6)$ & $14(21.5)$ & 0.000 \\
\hline Renal function recovery & $15(31.3)$ & $33(50.8)$ & 0.022 \\
\hline ICU admission & 37 (94.9) & $23(35.4)$ & 0.000 \\
\hline Mechanical ventilation & 37 (94.9) & $26(40.0)$ & 0.000 \\
\hline Vasopressors & $31(81.6)$ & $17(26.1)$ & 0.000 \\
\hline $\begin{array}{l}\text { In-hospital complications } \\
\text { Sepsis } \\
\text { Infection } \\
\text { No complications }\end{array}$ & $\begin{array}{c}19(48.7) \\
3(7.7) \\
2(5.1)\end{array}$ & $\begin{array}{l}16(25.0) \\
21(32.3) \\
17(26.1)\end{array}$ & $\begin{array}{l}0.013 \\
0.002 \\
0.004\end{array}$ \\
\hline Last available Scr & $2.90(1.10-3.70)$ & $1.00(0.80-1.65)$ & 0.000 \\
\hline Hospital lenght-of-stay days & $22(14-37)$ & $10(8-17)$ & 0.000 \\
\hline Mortality & $23(59.0)$ & $19(29.2)$ & 0.003 \\
\hline
\end{tabular}

In brief, prevalence was higher in males, the $\mathrm{sCr}$ at admission was normal and the predominant cause of AKI was MODS associated to COVID-19. The clinical course 
medRxiv preprint doi: https://doi.org/10.1101/2021.05.01.21256389; this version posted May 4, 2021. The copyright holder for this preprint (which was not certified by peer review) is the author/funder, who has granted medRxiv a license to display the preprint in perpetuity. It is made available under a CC-BY-NC-ND 4.0 International license.

was characterized by higher AKI stages, KRT requirement, higher incidence of organ dysfunction and complications, less recovery of renal function and higher mortality.

\section{Critically ill patients.}

A large proportion of patients needed to be admitted to the ICU $(622,71.5 \%)$ and $628(72.2 \%)$ were placed on mechanical ventilation. Table 8 shows the different characteristics between critically ill and no critically ill patients.

Table 8. Clinical characteristics by severity of clinical condition. Subgroup critically ill patients.

\begin{tabular}{|c|c|c|c|}
\hline Variable & $\begin{array}{l}I C U \\
622\end{array}$ & $\begin{array}{c}\text { No ICU } \\
221\end{array}$ & $\mathbf{P}$ \\
\hline Obesity n (\%) & $227(35.5)$ & $40(18.1)$ & 0.000 \\
\hline Proteinuira at admission & $195 / 295(66.1)$ & $46 / 91(50.5)$ & 0.023 \\
\hline $\begin{array}{l}\text { Hospital-acquired acute kidney } \\
\text { injury }\end{array}$ & $445 / 620(71.8)$ & $90 / 201(44.8)$ & 0.000 \\
\hline $\begin{array}{l}\text { Cause of acute kidney injury } \\
\text { SARS-CoV-2 MODS* } \\
\text { Sepsis MODS } \\
\text { Nephrotoxic drugs }\end{array}$ & $\begin{array}{l}432(69.5) \\
229(36.8) \\
113(18.2)\end{array}$ & $\begin{array}{c}66(29.9) \\
19(8.6) \\
65(29.4)\end{array}$ & $\begin{array}{l}0.000 \\
0.000 \\
0.002\end{array}$ \\
\hline Days COVID-hospital admission & $2(1-5)$ & $1(1-3)$ & 0.000 \\
\hline Scr at admission & $1.10(0.89-1.61)$ & $1.50(1.10-2.67$ & 0.000 \\
\hline White blood cells count $\mathrm{mm}^{3}$ & $10700(7800-14700)$ & 9600 (7295-13397) & 0.028 \\
\hline Ferritine $\mathrm{ng} / \mathrm{mL}$ & $1291(750-2000)$ & 647 (349-1190) & 0.000 \\
\hline $\mathrm{pH}$ & $7.39(7.30-7.42)$ & $7.41(7.30-7.45)$ & 0.004 \\
\hline $\mathrm{HCO} 3 \mathrm{mmol} / \mathrm{L}$ & $22(19-24)$ & $21(18-24)$ & 0.034 \\
\hline Days COVID-AKI onset & $4(2-9)$ & $1(1-3)$ & 0.000 \\
\hline
\end{tabular}


medRxiv preprint doi: https://doi.org/10.1101/2021.05.01.21256389; this version posted May 4, 2021. The copyright holder for this preprint (which was not certified by peer review) is the author/funder, who has granted medRxiv a license to display the preprint in perpetuity. It is made available under a CC-BY-NC-ND 4.0 International license.

Last available Scr $\mathrm{mg} / \mathrm{dL}$

Mortality
$3.00(1.43-4.40)$

314 (50.6)
$1.20(0.90-2.20)$

$35(15.8)$
0.006

0.000

Obesity, proteinuria, hospital acquired AKI and MODS related AKI, delay in hospital admission, higher values in white blood cells and ferritine and, as expected, higher mortality was the profile of this subset of patients.

\section{Discussion}

In early December 2019, an outbreak of an acute respiratory infection caused by SARSCoV-2 virus occurred in Wuhan City, China, which rapidly spread to other regions of China and later globally constituting a pandemic as was declared by WHO on March 11,2020 . The respiratory system is the primary target of the virus, but it was increasingly recognized that it could affect other organs, including kidneys leading to proteinuria, haematuria and AKI $[9,10,11]$. On the other hand, kidney impairment and mortality increases with disease severity $[5,12,13]$

The real incidence of AKI in COVID-19 is cause of debate. Early studies from China showed low AKI incidence (0.5\%) in a series of 1,099 hospitalized patients. [14]. Conversely, a large series of 5,449 patients admitted to 13 academic and community hospitals in New York, identified 1,993 patients with AKI (36.6\%) [5], an incidence close to the $33.9 \%$ reported in 35,302 patients from the largest hospital discharge database in USA (Premier Healthcare Database) [15]

Currently, America is the epicenter of COVID-19 pandemic being the impact devastating on the Latin America subcontinent $[16,17,18]$. The rapid spread of the infection, the work overload of health teams, the uneven level of health systems in the 
medRxiv preprint doi: https://doi.org/10.1101/2021.05.01.21256389; this version posted May 4, 2021. The copyright holder for this preprint (which was not certified by peer review) is the author/funder, who has granted medRxiv a license to display the preprint in perpetuity. It is made available under a CC-BY-NC-ND 4.0 International license.

region, and the differences in strategies in the fight against the pandemic between countries, partly explains the lack of data in a region, that otherwise has scarce general epidemiological information on AKI [19].

In order to improve gaps in the knowledge of kidney disorders associated with COVID19 in the region the AKI Committee of the Latin American Society of Nephrology and Hypertension conducted a Registry that gathered data of 870 patients from 57 cities distributed in 12 countries in which the elderly male prevailed. Our population showed a high burden of comorbidities, since $87.2 \%$ had at least one associated disease, mainly hypertension, diabetes and obesity. Moreover, severe clinical condition at hospital admission was also predominant (86\%). Finally, time elapsed between diagnosis of COVID-19 and hospitalization was short, what can be read as a marker of severity of the disease. It is not surprising therefore, that in-hospital mortality was high (62.5\%), greater than reported in other studies $[5,12]$. In contrast with the severity of SASRCoV-2 infection at admission, renal and metabolic condition appeared to be less affected. In most of the cases, sCr level was near normal, as well as serum potassium and acid-base status. However, evidence of ongoing kidney impairment at admission was demonstrated since in $62.4 \%$ of the patients in whom a urine dipstick test was performed had proteinuria. With regard to AKI profile, the onset occurred shortly after COVID-19 diagnosis and was linked in the vast majority of cases to COVID-19 MODS and hypovolemia. As previously reported, the onset of AKI was mainly during hospital stay prevailing a non-oliguric pattern [5] and severe forms. An additional burden of seriousness was due to in-hospital complications, mostly sepsis (50.4\%). 
medRxiv preprint doi: https://doi.org/10.1101/2021.05.01.21256389; this version posted May 4, 2021. The copyright holder for this preprint (which was not certified by peer review) is the author/funder, who has granted medRxiv a license to display the preprint in perpetuity. It is made available under a CC-BY-NC-ND 4.0 International license .

In previous studies variable degrees of proteinuria were reported among COVID-19 patients, ranging between $33 \%$ and $74 \%$ with a higher incidence among AKI stages $2-3$ (11) and it was invariably associated to worse outcome $[5,9$,$] . Histopathological studies$ showed a diversity of presentations like collapsing glomerulopathy, thrombotic microangiopathy, minimal change disease, immune-mediated glomerulopathy and acute tubular necrosis $(20,21)$. We assessed the presence of proteinuria at admission and through patients' hospital stay (de novo proteinuria). By doing that, we identified two patterns of proteinuria having interesting different characteristics between them. Group I patients' (proteinuria at hospital admission) had more comorbidities, were admitted with impaired renal function, had a worse course of their illness leading to a significant rise in mortality rate, as can be seen in Table 5. On the other hand, Group II patients (de novo proteinuria) had normal kidney function at hospital admission, which would anticipate a better outcome. However, in most of the cases their clinical condition worsened requiring multi-organ support, recovered renal function less frequently, had prolonged hospital stay and a higher mortality rate (Table 6). To our knowledge, the latter pattern of proteinuria that portends poor results has not been reported previously being one of the most relevant findings of our study. In both groups, SARS-CoV-2 MODS was recognized by far as the main cause of AKI that strongly suggests glomerular and tubular damage due to severe inflammation, together with associated hemodynamic disturbances. These results lead us to strongly recommend including a urine dipstick test in the routine evaluation of COVID-19 patients for a timely detection of kidney injury.

As previously reported, AKI is associated to higher risk of death in COVID-19 patients $[5,15,20]$. Our study found higher than usual mortality rate, probably due to a selection 
medRxiv preprint doi: https://doi.org/10.1101/2021.05.01.21256389; this version posted May 4, 2021. The copyright holder for this preprint (which was not certified by peer review) is the author/funder, who has granted medRxiv a license to display the preprint in perpetuity. It is made available under a CC-BY-NC-ND 4.0 International license.

bias since our Registry is an open repository of patients provided by selected physicians (nephrologists). We found as many as 24 variables associated with mortality in the univariate analysis. Unfortunately, some of them could not be included in a regression model because of inconsistence of data or high number of patients with missing data. With these limitations, we identified nine variables that were independently associated to in-hospital mortality. Older age (OR 0.96, 95\% IC 0.940.99); heart disease (OR 2.87, 95\% IC 1.14-7.19); fluid depletion (OR 2.18, 95\% IC 1.084.42) and COVID-19 MODS (OR 2.21, 95\% IC 1.05-4.65) as cause of AKI; non-recovery of renal function (OR 31.72, 95\% IC 15.46-65.08); critically ill condition (OR 38.54, 95\% IC 11.86-125.17); use of vasopressor (OR 3.95, 95\% IC 1.51-10.32); some in-hospital complications (OR 3.30, 95\% IC 1.42-7.79) and hospital length-of-stay (OR 1.05, 95\% IC 1.02-1.07). Of note, $\mathrm{s} C r$ requested at three time points (admission, peak, discharge) did not enter in the model.

Our study has some limitations. First, its design as a repository of patients promote the individual participation in addition to that of institutions, as desired. In return, entail some heterogeneity in the quality of information resulting in some variables having a high proportion of missing data that forced us to exclude them from the analysis. Consequently, potential unmeasured confounder may not have been identified. Second, the limited ability to access the universe of millions patients did not allow us to establish incidence, which is a very relevant information, particularly considering that is a controversial and open point. Third, data of patients was provided by the participants and not as a result of the review of clinical charts by the research team. We also acknowledge some strengths. First, to date this is the largest multicenter study involving a large number of countries and cities from Latin America. Second, data 
medRxiv preprint doi: https://doi.org/10.1101/2021.05.01.21256389; this version posted May 4, 2021. The copyright holder for this preprint (which was not certified by peer review) is the author/funder, who has granted medRxiv a license to display the preprint in perpetuity. It is made available under a CC-BY-NC-ND 4.0 International license.

requested were organized in six forms with 47 questions with the aim to fully explore the more relevant problems related to SARS-CoV-2 infection and kidney disease. With this approach, two different patterns of patients with proteinuria having relevant prognostic value were clearly identified.

In conclusion, this is the first multinational Registry of patients with renal impairment associated to SARS-CoV-2 infection in Latin America. The data of 870 patients from 14 countries generally shows similar disease profile to previously reported series regarding to demographic, underlying condition, AKI features, impact on distant organs and mortality. The study highlights the value of assessing proteinuria throughout the clinical course for a timely identification of renal impairment and potential adverse outcomes. Our results cannot be generalized, as it is a repository of patients that partially represents the universe of this condition. However, this study demonstrates the feasibility of carrying out similar studies in order to expand the knowledge of this new disease that remains to be fully characterized.

\section{Acknowledgments.}

We would like to thank all the clinical staff and the hospitals that were part of this 57 collaboration in 12 countries, for supporting this project.

\section{Authors contribution}

Conceptualization and design: RL, AF, RCD, MYI, LY, EAB

Data curation: RL

Acquisition of data, analysis and interpretation: all authors

Drafting the manuscript: $R L, A F, D P, R C D$ 
References

1. Burki T. COVID-19 in Latin America. Lancet Infect Dis. 2020;20:547-478

2. Dyer O. COVID-19 hot spot appear across Latin America. BMJ 2020;369:m2182

3. Miller MJ, Loaiza JR, Takyar A, Gilman RH. COVID-19 in Latin America: Novel transmission dynamics for global pandemic? PLoS Negl Trop Dis. 2020; $14: e 0008265$

4. Richardson S, Hirsch JS, Narasimhan M, et al. Presenting characteristics, comorbidities and outcomes among 5700 patients hospitalized with COVID-19 in the New York City Area. JAMA 2020;323:2052-2059

5. Hirsch JS, Ng JH, Ross DW et al. Acute kidney injury in patients hospitalized with COVID-19. Kidney Int. 2020;98:2019-218

6. Murugan R, Karajala-Subramanyam V, Lee M et al. Acute kidney injury in nonsevere pneumonia is associated with and increased immune response and lower survival. Kidney Int 2010;77:527-535

7. Wang F, Ran L, Qian C et al. Epidemiology and outcomes of acute kidney injury in COVID-19 patients with acute respiratory distress syndrome: a multicenter retrospective study. Blood Purif 2020;1-7

8. Rizo-Topete LM, Claure-Del Granado R, Ponce D, Lombardi R. Acute kidney injury requiring renal replacement therapy during the COVID-19 pandemic: what are our options for treating it in Latin America? Kidney Int. 2021; 99:524-29 
medRxiv preprint doi: https://doi.org/10.1101/2021.05.01.21256389; this version posted May 4, 2021. The copyright holder for this preprint (which was not certified by peer review) is the author/funder, who has granted medRxiv a license to display the preprint in perpetuity. It is made available under a CC-BY-NC-ND 4.0 International license .

9. Zheng $X$, Yang $H$, Li X, et al. Prevalence of kidney injury and associations with critical illness and death in patients with COVID-19 Clin J Am Soc Nephrol $15: 1549,2020$

10. Shetty AA, Tawhari I, Safar-Boueri L, et al. COVID-19-Associated Glomerular Disease. J Am Soc Nephrol. 2021;32:33-40

11. Pei G, Zhang Z, Peng J, et al. Renal Involvement and Early Prognosis in Patients with COVID-19 Pneumonia. J Am Soc Nephrol. 2020 Jun;31(6):1157-1165

12. Gupta S, Hayek SS, Wang W, et al. Factors associated with death in critically ill patients with coronavirus disease 2019 in the US. JAMA Intern Med. 2020;180:1436-1446.

13. Cheng $\mathrm{Y}$, Luo $\mathrm{R}$, Wang $\mathrm{K}$ et al. Kidney impairment is associated with inhospital death of COVID-19 patients. Kidney Int 97:829-838, 2020

14. Guan W-J, Ni Z-Y, Hu Y, et al. Clinical characteristics of coronavirus disease 2019 in China. N Engl J Med. 2020;382:1708-1720.

15. Rosenthal N, Cao Z, Gundrum J, et al S. Risk Factors Associated With In-Hospital mortality in a US National Sample of patients with COVID-19. JAMA Network Open. 2020;3:e2029058).

16. Cimerman S, Chebabo A, Cunha CAD, Rodriguez-Morales AJ. Deep impact of COVID-19 in the healthcare of Latin America: the case of Brazil. Braz J Infect Dis. $2020 ; 24: 93-5$.

17. Barberia LG, Gomez EJ. Political and institutional perils of Brazil's COVID-19 crisis. Lancet. 2020;396:367-8.).

18. Zamoner W, Santos CADS, Magalhães LE, et al. Acute Kidney Injury in COVID-19: 90 Days of the Pandemic in a Brazilian Public Hospital. Front. Med. 8:622577 
medRxiv preprint doi: https://doi.org/10.1101/2021.05.01.21256389; this version posted May 4, 2021. The copyright holder for this preprint (which was not certified by peer review) is the author/funder, who has granted medRxiv a license to display the preprint in perpetuity. It is made available under a CC-BY-NC-ND 4.0 International license.

19. Lombardi R, Ferreiro A, Claure-Del Granado R, et al. EPILAT-IRA Study: A contribution to the understanding of the epidemiology of acute kidney injury in Latin America. PLoS ONE 14:e0224655.

20. Su $\mathrm{H}$, Yang $\mathrm{M}$, Wan Ch, et al: Renal histopathological analysis of 26 postmortem findings of patients with COVID-19 in China. Kidney Int. 2020;98:219-227.

21. Sharma P, Uppal NN, Wanchoo R, et al. COVID-19-Associated Kidney Injury: A Case Series of Kidney Biopsy Findings. J Am Soc Nephrol. 2020 31:1948-1958

22. Thakkar J, Chand S, Aboodi MS, et al. Characteristics, outcomes and 60-day hospital mortality of ICU patients with Covid-19 and acute kidney injury.

Kidney360 December 2020, 1:1339-1344 
medRxiv preprint doi: https://doi.org/10.1101/2021.05.01.21256389; this version posted May 4, 2021. The copyright holder for this preprint (which was not certified by peer review) is the author/funder, who has granted medRxiv a license to display the preprint in perpetuity.

It is made available under a CC-BY-NC-ND 4.0 International license .

1

Fig 1. Patients per country

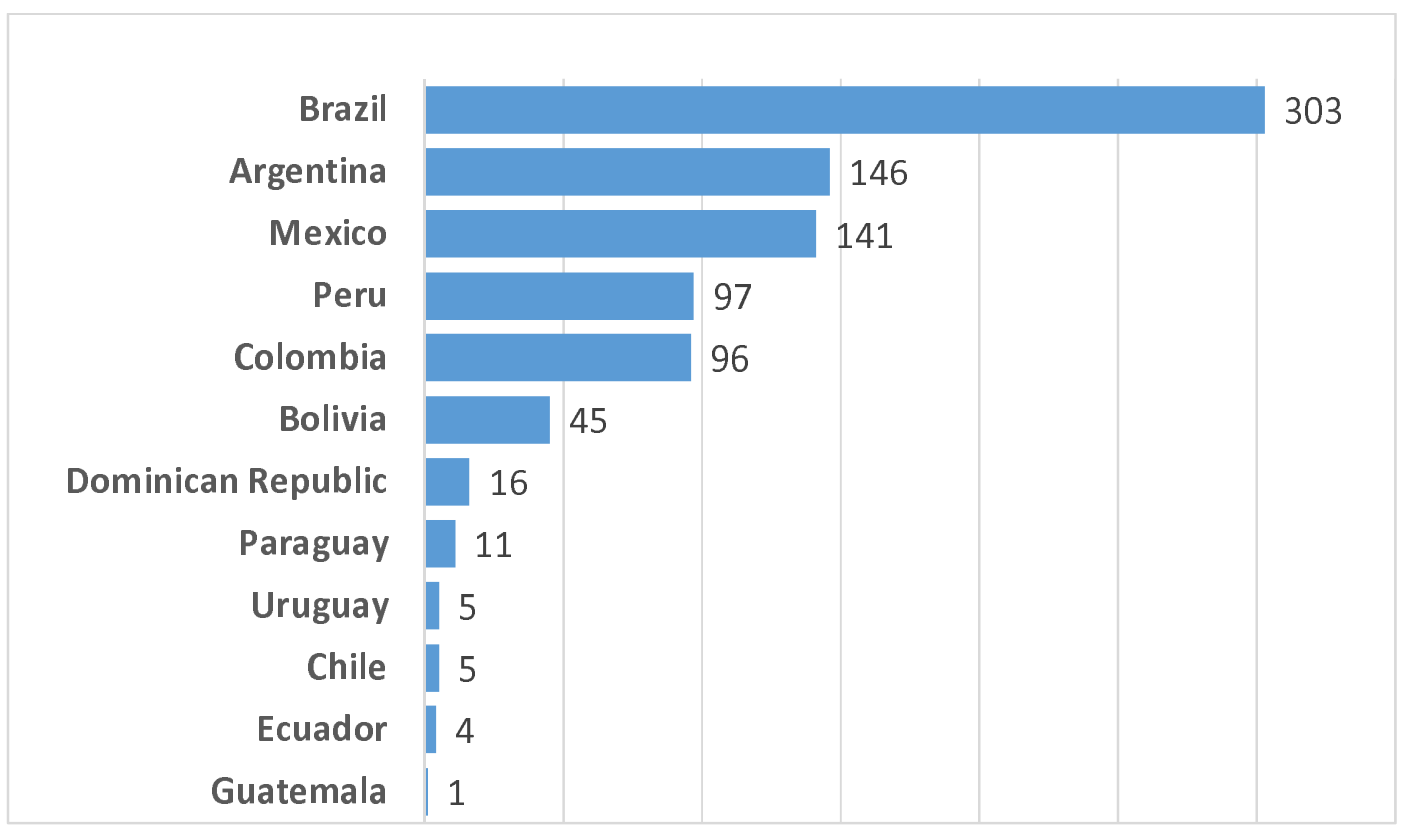

